\title{
The Influence of Mould Strength on Shrinkage Production for Castings with Different Wall Thickness for Material EN-GJS-400-18LT
}

Martin Conev, Iveta Vasková, Martina Hrubovčáková

Department of Ferrous Metallurgy and Foundry, Faculty of Metallurgy, Technical University in Košice, Slovakia, Email:martin.conev@tuke.sk, iveta.vaskova@tuke.sk,martina.hrubovcakova@tuke.sk

This paper is dealing with the influence of mould strength on a shrinkage production for ductile iron castings. According to pressures that impact a mould cavity the strength of mould is an important parameter by ductile iron pouring. During the solidification of cast iron a non-metallic particle - graphite is released. Depending on graphite amount released in the liquid and in the solidified skin of casting the tendency to shrinking is varying. In the experiment a furan sand mixture is used. The experiment compares a size of the created shrinkage in the castings with different wall thickness poured into a moulds with different strength. For the occurrence of shrinkage and its size evaluation a non-destructive ultrasonic reflecting method was used.

Keywords: Ductile iron, furan sand mixture, strength of mould, shrinkage, ultrasonic testing

\section{References}

[1] JELÍNEK, P. (2004). Pojivové soustavy slévarenských formovacích směsí, Ostrava.

[2] ZEITSCH, K. J. (2000). The Chemistry and Technology of Furfural and its Many By-products. Elsevier, Netherlands.

[3] TÓTH, J., PUŠKÁŠ, J. (1971). Organická chémia. Nitra.

[4] RECKNAGEL, U., IVANOV, S. (2012). Určování vytvrzovacích vlastností samotvrdnoucích formovacích směsí pojených syntetickými pryskyřicemi prrímo ve slévárně. In: Slévárenství, Vol. 3-4, pp. 100 - 104. Czech Republic.

[5] NOVÁ, I., MACHUTA, J. (2014). Monitoring Methods the Properties and Structure of Grey Iron Castings. In: Manufacturing Technology. Vol. 14, No. 2, pp. 223 - 228. UJEP. Czech Republic

[6] GEDEONOVÁ, Z. (1990). Teória zlievárenských pochodov. Alfa, Košice.

[7] KARSAY, S.I. (1976). Ductile Iron vol. 1 - Production. QIT - Fer et Titane Inc, Montreal.

[8] KRIEDEL, M. (2011). Ultrazvuková defektoskopie. Starmans electronics, Praha.

[9] DEUTSCH, V., PLATTE, M., VOGT, M. (1997). Ultraschallprüfung-Grundlagen und industrielle Anwendungen. Springer, Berlin.

[10] ANDRŠOVÁ, Z., SKRBEK, B. (2012). The use of magnetic and ultrasonic structuroscopy for inspection of ADI/AGI castings. In: Manufacturing Technology. Vol. 12, No. 13, pp. 93 - 97. UJEP. Czech Republic

[11] VRZGULA, P., FATURÍK, M., MICIAN, M. (2014). New Inspection Technologies for Identification of Failure in the Materials and Welded Joints for Area of Gas Industry. In: Manufacturing technology. Vol. 14, No. 3, pp. 487-492. UJEP. Czech Republic.

[12] SKRBEK, B. (2001). Ultrasonic testing of internal defects of castings from spheroidal graphite cast iron - comparison with radiographic methods. In: Slévárenství, Vol. 7-8. Czech Republic.

[13] KONAR, R., PATEK, M., ZRAK, A. (2015). Ultrasonic Testing of Non-ferrous Materials in the Foundry Industry. In: Manufacturing Technology. Vol. 15, No. 4, pp. 557 - 562. UJEP. Czech Republic.

[14] BELAN, J. (2010). Identification of cast iron type with using of NDT methods. In: Archives of foundry engineering. Vol. 10, No. 1. Poland.

[15] NOVA, I., MACHUTA, J. (2014). Monitoring Methods the Properties and Structure of Grey Iron Castings. In: Manufacturing Technology. Vol. 14, No. 2, pp. 223 - 228. UJEP. Czech Republic.

[16] DIN EN 12680 - 1. (2003). Gießereiwesen, Ultraschallprüfung. 